\title{
Self-government in the political system of Poland
}

\begin{abstract}
One of the greatest achievements in the process of political transformation in Poland involves the broad decentralization of the public authorities, where a larger number of independent entities with public competences exist alongside a single center. Decentralization is embodied by self-government, which has therefore become an important element of the democratic regime co-creating a network of links related to the distribution of power, property and resources across society. Undoubtedly, selfgovernment which works in favor of citizens' groups being organized as corporations contributes to the increased efficiency of public authorities in the territorial and special dimension. Based on this, self-government should be understood not as a unidimensional entity involved only in territorial relations. There is also special self-government, established according to different criteria, which plays an important role in the system of the representation of the interests of defined circles. It is divided into professional self-government and, first and foremost, business self-government. Importantly, selfgovernments should be approached from a slightly different angle - not only in the administrative and institutional context, but also from the point of view of the realization of the interests of organized social groups, that is in terms of governance, which can improve the functioning of local authorities, for instance as concerns the emergence of metropolitan areas. The harmonious development of all forms of self-government, irrespective of the type of bonds connecting its members, as well as the consolidation of participatory processes, is one of the prerequisites for a stable democratic regime.
\end{abstract}

Key words: political system, local self-government, special self-government

\section{Introduction}

A fter thirty years of self-governments functioning in Poland, a reflection on the quality and durability of the political reform launched at that time is welcome. Over time we can see that the extensive decentralization of public governance resulted in the genuine empowerment of Polish society. Local self-government was a key factor in this process being an important element of the political system in Poland. The first stage in the process was marked by the adoption of the Law on local self-government (at present: municipal self-government) on March 8, 1990, which laid the foundation for the reinstatement of local governance and commenced further decentralization reforms, later concluded by the establishment of local self-governments at the district and provincial levels. The implementation of these local self-governments resulted in the establishment of the three-level territorial division of Poland, into municipalities (Polish: gmina), districts (Polish: powiat) and regions (Polish: województwo), as of January 1, 1999. Such an advanced degree of decentralization generated local self-governments at every level of governance. The structure of local self-government can be considered coherent in formal and legal terms. Municipal, district and provincial self-governments are perceived to be significant units of public administration, despite certain reservations as regards the 
division of powers and ways of generating their budgetary income. It is however clear that the traditional format of local policy is becoming exhausted. It appears that other, external entities should increasingly be incorporated into the governance structures to facilitate and rationalize public decision-making, which has a direct bearing on the socioeconomic development of a given area.

Like numerous other spheres of public life, local governance is also transforming due to the advancing processes of globalization, urbanization, European integration, participatory democracy and technological progress. Recently, a trend towards multilevel governance has emerged, producing complicated templates of vertical and horizontal relations between various circles, social groups and organizational forms of self-government. This trend has resulted in blurred borderlines and the emergence of new economic and political spaces (Rajca, 2010, p. 23). That is why self-government needs to be examined from a slightly different perspective now, due to its administrative and institutional context on the one hand, and, on the other, from the perspective of the interest of organized social groups, that is, in terms of governance.

Another important angle involves the multidimensionality of self-government. It should be realized that another entity that plays an important role in the representation of the interest of defined groups of people is special self-government. ${ }^{{ }^{*}}$ Operating as associations under public law, the membership of which is mandatory, special self-government bodies perform the tasks of the decentralized portion of state administration on a par with self-government entities.

Within special self-government, business associations, representing the interests of business circles, and personal associations, whose task is to advocate for the interests of persons exercising professions of public trust, should be distinguished first and foremost. Thus, special self-government is divided into business self-government and professional self-government respectively.

When consolidating participatory processes, broadly understood decentralization should be pursued as one of the foundations of a democratic political system. One has to realize that decentralization is a historical process, an ongoing phenomenon the intensity of which varies depending on the direction of socio-political transformations, and as such it is unfortunately reversible. It is therefore advisable to retain self-government, which is an embodiment of decentralization, as an essential element of the political system, and thereby maintain the influence society has on public decision-making processes.

\section{Self-government in the political system of Poland}

In general, a system is understood in terms of an internally coordinated arrangement of elements that is designed to perform certain functions and is distinguished from its surroundings. The interrelations between its elements form the system's structure, which

${ }^{1}$ In Polish, self-government (Polish: samorzad) is used with reference to local governments (local administration), as well as business and professional self-regulatory associations, or 'special self-governments'. In order to maintain consistency with the original text, the term 'self-government' is used in the paper to refer to all three types of entities: local governments, business chambers and professional associations [translator's note]. 
is the main property that distinguishes a system from an unorganized set with accidental relations. In other words, a system defines all the mutually related elements which form a permanent, interdependent whole that shares uniform properties and operating principles.

According to Bogusław Jagusiak, the term system was applied to define and examine the realm of politics primarily because of the politicization of human existence. The political system is one of the fundamental notions in political science and defines a basic structure of political life (Jagusiak, 2011, p. 9).

Konstanty Adam Wojtaszczyk defines the political system as all the state bodies, political parties and social organizations and groups, both formal and informal, which participate in political activities within a given state, as well as the general principles and rules regulating mutual relations between them (Wojtaszczyk, 2003, p. 236).

Andrew Heywood in turn stresses the fact that the political system is a network of connections related to the division of power, assets and resources in society. The political system, or political regime, embraces governance mechanisms and state institutions on the one hand and structures and processes allowing them to cooperate with the entire society on the other (Heywood, 2006, p. 30).

The approaches of the above-mentioned authors accommodate the broadly understood concept of self-government, which operates for the benefit of corporate groups of citizens and increases the effectiveness of public authorities operating in the territorial and special dimension.

At the local level, self-government can be recognized as a significant manifestation of the public authorities, or even political power, as stressed by Andrzej Antoszewski, who writes about self-government being political, stressing the fact that it is the subject of political pursuit and of the competition of political parties, as indicated by Zbigniew Leoński. Andrzej Antoszewski notes that even though it is not within the authority of self-governments to exercise the main prerogative of political power, namely to specify the access to and principles of ruling (these are established by entities other than selfgovernments), this does not change the key role self-governments play in the process of the decentralization of state administration (Antoszewski, 2008, pp. 52-53).

The development of local governance promotes the stabilization of the democratic political system, which pursues the model of multi-dimensional, consolidated democracy. This is due to the fact that such stabilization includes competitive elections, but also factors such as the separation of powers, the absence of decision-making centers that are not monitored by voters, restrictions on the executive, respect for civil rights, a relatively stable party system, and the existence of civil society. Equally important, stable democracies are those that have confirmed, in the long run, their ability to survive, including the ability to deal with crises (Antoszewski, Herbut, 2001, p. 21).

A political system forged under such conditions is characterized by the following properties:

1) elections are a mechanism providing access to power and enforcing the political responsibility of those in power;

2) elections are competitive, cyclical and ensure the equal treatment of all participants by state authorities;

3) no actions are taken by the government that would directly limit the possibility of alternating power; 
4) the freedom of association for political purposes, and the freedom to express political views and criticize the government, are legally and effectively guaranteed (political opponents of the government are not subject to repression);

$5)$ every adult citizen may apply for a deputy's mandate; the only exception being the prohibition stipulated in the law and the court's ruling based on this law (Antoszewski, Herbut, 2001, p. 22).

The above list pertains more to the institutional dimension of the political system which is identified with the state regime. The political system is understood here as all persons, groups and organizations, and their mutual relations and cooperation; or as the entities exerting dominating influence on the development, implementation and interactions of regulations governing the internal life of a given society (Podolak, Żmigrodzki, 2009, p. 12).

In the light of the considerations in this paper, the structural-functional approach seems to be more appropriate, as it views political systems as dynamic processes taking place within individual communities, and the core of these systems is to process social stimuli into the political decisions and actions of various entities, such as the state, local governments, and associations of entrepreneurs and organizations that represent persons working in the professions of public trust. Individual entities enter into political relations, thereby changing their non-political roles into political ones. Needless to say, the best solution would be to combine the functional and institutional (juridical) approach, because this would make it possible to demonstrate the structures and institutions in action (Jagusiak, 2011, pp. 16-17).

The self-government is clearly an important element of the political system thus understood. According to Jarosław Och, it materializes in practice the fundamental ideal of the democratic political order, namely the decentralization of the decision-making structures of the state. Studies in political science indicate that the democratic mechanism of modern states relies on decentralization, on political plurality, freedom of expression of ideologies and opinions, and on the rule of law (Och, 2014, p. 175). Therefore, selfgovernance consolidates democratic processes as reflected in the numerous conventions and documents which define decentralization standards in Europe. For example, the Preamble to the European Charter of Local Self-Government emphasizes the significance of self-governance for the construction of Europe. Democracy and decentralization are indicated as the two fundamental principles of European integration. The core values associated with the broadly understood ideal of local self-governance are stressed by Joachim Osiński. He believes that the articulation and dissemination of these values is of utmost importance in any attempts at reform in this field. These values are embraced within a certain global image of the local system, on the one hand, and on the expectations and hopes raised in local communities, on the other. The reforms launched in this field should produce the democratization and decentralization of state power (Osiński, 1999, p. 59).

Stanisław Zyborowicz observes that it is practically unfeasible to discuss self-governance without associating this term with democracy. Undoubtedly, the ideal of self-governance is among the significant categories of political theory in the field of the political system (Zyborowicz, 2008, p. 51). The growing importance of local government in modern political systems is emphasized in political science studies. Zbigniew Blok identifies 
the premises of this process, indicating the requirement to rationalize operations on the one hand and meet the demands on the other (Blok, 1996, pp. 51-52).

We can therefore agree that the development of self-government is associated with the democratization of political systems. There are reasons why we acknowledge the fact that the emergence of modern self-governance was the outcome of the fundamental socio-political transformation at the turn of the eighteenth century which facilitated the consolidation of civic democracy and the rule of law. This process recurred in successive decades and centuries albeit in different political conditions. This was the case in Italy, among others, which, by virtue of the Constitution of December 22, 1947, launched decentralization processes after the period of the fascist regime. The long period of the authoritarian regime of General Francisco Franco was followed be self-government reforms in Spain.

Similarly, the departure from decentralization principles was a harbinger of the curtailment of civic freedoms and the crisis of democratic institutions.

The experience of Poland confirms the above regularities. This is particularly true for the evolution of the political system of the Second Republic of Poland in which selfgovernment was initially intended to play a significant role.

The Constitution of March 17, 1921 expressed the republican form of governance providing for the Republic of Poland to establish its regime on the principle of broad local governance, by transferring the respective scope of legislature to the representatives of self-governments, especially in the fields of administration, culture and economy. This scope should be determined in detail by virtue of appropriate legal acts (Article 3 ). The Constitution provided for the establishment of three levels of self-government in line with the administrative division of the state and for the association of local governance units (Article 65); stipulated the principles of how self-government units should be formed and rule within their assigned scope of operation (Article 67); and addressed the matter of state supervision over self-governments (Article 70) (Adamczyk, Pastuszka, 1985, pp. 234-235; Ajnenkiel, 1982, p. 258; Dolnicki, 1999, pp. 45-46).

Although it is true that the March Constitution granted extensive powers to self-governments, the implementation of its highly general provisions somewhat deviated from the political practice, which can be demonstrated by the absence of uniform nationwide regulations pertaining to self-government at the provincial level. Another factor bearing on the status of self-governments was that the legislative work on a uniform law to provide for its operations did not finish until 1933.

The situation of self-government deteriorated in the wake of the May Coup in 1926. Although sham democratic institutions continued to work in Poland, the country's evolution towards an authoritarian regime had begun (Luczak, 1973, pp. 66-67). The Sanation Camp did not question the formal and legal position of self-government but decidedly opposed the influence of political parties on local governance. The government initiated this trend, rejecting the idea of great local governance laws and leading to the adoption of the little law on local governance concerning a partial change of the self-government system on March 23, 1933 (Ustawa z dnia 23 marca 1933 r. o częściowej zmianie ustroju samorzadu terytorialnego, Dz. U. [Journal of Laws of the Republic of Poland] 1933, No. 35, item 294).

This regulation granted state administration bodies a broad range of supervisory authority over self-government units. Central government continued to enjoy its earlier powers, such as approving the election of municipality heads, and the powers 
exercised instead of self-government bodies at the provincial level, while obtaining a range of additional new competences, such as approving the resolutions of municipal councils regarding the status of administrative staff, establishing the obligation to appoint a professional municipal supervisor, approving the resolution on the appointment or dismissal of a municipal secretary, or approving the election of the village head. Only in some of these cases did the respective body of central administration operate with civic participation.

The 1933 regulation consolidated the powers of the supervisory authorities, both in respect of the acts of self-government bodies and these bodies themselves. The premises for the dissolution of the decision-making body and the managing body together, or separately, which was a novelty, were determined in a general, and therefore not clear, manner. This created the possibility for the unhampered dissolution of self-government bodies, which the government used repeatedly, appointing forced administrators until the newly elected self-government bodies were constituted (Izdebski, 1991, p. 47).

It can be seen from the above that as authoritarian solutions were implemented in the political system of the Second Republic, self-government was increasingly subordinated to the central administration. These trends materialized to the greater extent in the April Constitution of 1935. According to Article 75 of this Constitution, "the self-government should perform the tasks of state administration within the scope of local needs" (Bombicki, 1998, p. 64). This marked a clear step backwards compared to the constitutional provisions of 1921. The April Constitution sanctioned the legal status initiated by the changes after the May Coup and confirmed by the Act of 1933.

A similar evolution could also be seen at the time of the communist regime forming in Poland. Immediately after World War Two, self-government was reinstated by virtue of a Decree of November 23, 1944 on the organization and scope of operation of self-government (Dekret z dnia 23 listopada 1944 r. o organizacji i zakresie działania samorzadu terytorialnego, Dz. U. 1944, No. 14, item 74). The Decree formally referred to the dual model of local administration existing in the Second Republic. It was made up of two co-existing subsystems, namely the subsystem of central (government) administration and that of the associations of self-governments operating through their respective legislative and executive bodies (Decree of August 28 on the procedure for appointing the authorities of the first and second instance).

The administrative structures of the reviving state appear to have been determined through tactical concerns, since it was easier to transform the system referring to the solutions that society had already been familiar with rather than implementing radical changes that would be perceived by the public as the sovietization of Poland. On the other hand, the new government made a formal reference to the provisions in the March Constitution of 1921, which provided for dual local administration and extended local governance.

The Decree on local governance was strictly related to the Law of September 11, 1944 on the organization and scope of the operation of national councils (Ustawa $\mathrm{z}$ dnia 11 września 1944 r. o organizacji i zakresie działania rad narodowych, Dz. U. 1944, No. 5, item 22), which recognized national councils as the decision-making bodies of self-governments. These were only provisional solutions, however, and as the new, highly centralized political system solidified, steps were taken to eliminate local governance from the realm of public authorities. 
Local governance was formally abolished in Poland by virtue of the Law of March 20, 1950 on the local bodies of uniform state authorities (Ustawa z dnia 20 marca $1950 \mathrm{r}$. o terenowych organach jednolitej władzy państwowej, Dz. U. 1950, No. 14, item 138). Following the Soviet doctrine, after 1950 the concept of local and supra-local representative bodies typical of democratic societies was rejected. It was not until the transformation in the 1980s and 1990s that the concept of municipal self-government was revisited, to include the supra-municipal (district) and regional (provincial) level.

Returning to the ideal of local governance in the conditions of the reviving democratic state was difficult and called for commitment on the part of the political elite, on the one hand, and approval on the part of society on the other. Yet the position and role of self-government in the administrative state structure were far from being generally understood. This was the aftermath of the over forty years of the centralized state model, in which all social activity aroused the concerns of the authorities as it could impair the omnipotent structure of the party and the government.

The steps launched in the early 1990s brought about material and favorable outcomes. They facilitated the genuine decentralization of public authorities and empowered the inhabitants of municipalities, districts and regions. Referring to self-governance was recognized as one of the foundations of the regime of the Third Republic. It was interpreted as being the antithesis to the authoritarian system that had been in force before 1989, which had curbed the freedom and public rights of the public. Local governance was expected "to mark the limits for the absolute power of the state" and provide a form of society's self-defense against the bureaucracy of the centralized state (Kroński, 1932, p. 8). The reforms launched at that time gradually expanded the scope of operation primarily of self-government that became a significant element of the political system.

In order for self-governments to become independent entities in a political system appears extremely difficult unless relevant constitutional regulations are stipulated. Under such regulations, self-governments become durable and stable, and their significant role in performing the tasks resulting from the decentralization of state administration is confirmed. The degree of detail in the regulations stipulated in the constitution depends on the political system adopted by the state. Certain differences can be seen in this respect between unitary, federal and regional states. Another element which is significant from the point of view of the development of institutions involves political practice and the quality of public entities' operations. In stable democracies, the matters concerning selfgovernments are not necessarily stipulated in detail in their respective constitutions. The constitutions in some states, for instance in Norway, fail to mention self-government, which nevertheless exists and operates on the basis of an unwritten constitutional tradition. Joachim Osiński notes that in all Nordic states constitutional regulations pertaining to self-government are extremely modest, not to say cursory, and are usually contained in one or two articles. For example, Article 82 of the Constitution of Denmark stipulates the following: "The right of municipalities to manage their own affairs independently, under State supervision, shall be laid down by statute" (Osiński, 1999, p. 60). In contrast to that, the Constitution of Ukraine of June 28, 1996, and the Constitution of the Republic of Belarus of November 24, 1996, feature seven and eight articles respectively, which in no way translates into the greater empowerment of local communities. What is important is therefore the quality of political institutions, which is the outcome of the level of 
democratic development, and the broadly understood self-governance culture of society which naturally creates participatory behaviors. This does not change the fact that, from the point of view of accelerating democratic processes, it is important to support decentralization trends in the constitution.

The legislator in Poland devoted a considerable space to self-government in the Constitution of the Republic of Poland of April 2, 1997. Considering the principle of subsidiarity addressed in the Preamble, one can state that self-government is recognized to be an integral element of the system of public authorities exercising their powers. Article 15 emphasizes the fact that the territorial system of the Republic of Poland provides for the decentralization of public authorities. Article 16 stipulates that the inhabitants of the basic units of the territorial division constitute a self-governing community by law (Konstytucja Rzeczypospolitej Polskiej z dnia 2 kwietnia 1997 r.). More detailed regulations on self-government are spelled out in Articles 163-172 in Chapter VII of the Constitution. Among other things, they include a general clause whereby self-government is authorized to perform public tasks, they envisage the possibility of multi-level self-governments, address the matter of property law and the property rights of self-governments, consider the sources of income of self-government entities, and determine the principles and procedure of elections to self-governments; as well as emphasize the importance of self-government referendum, the essence of supervision over self-government, and the issues associated with the possibility of self-government entities to associate. Such extensive concern with local governance in the Constitution clearly consolidates the position of self-governments and follows the provisions contained in the European Charter of Local Self-Government. ${ }^{2}$

Yet it is obvious that the dynamics of socio-political and economic processes sometimes requires adopting an often innovative view on the system of public authorities which goes beyond the literal provisions of the Basic Law. This is also true for self-government formed by the inhabitants of a given territory in order to make decisions aimed at fulfilling the municipal, existential and cultural needs of the local community concerned. It is of utmost importance in this context to increase social participation at the level of self-government.

Public involvement in democratic processes is most often analyzed through voter activity. This is the main way to exercise the constitutional principle of the supremacy of the nation. When seeking more active forms for exercising power in the area of local governance, the possibilities offered by direct democracy have to be taken into account. The fundamental forms of direct democracy have long been identified to include referenda, social consultations, rural gatherings (gatherings of the inhabitants of the estate) as well as the right to initiate resolutions, which inspires certain hopes with regard to increasing public participation in the local political system.

The right to initiate resolutions is defined as the power enjoyed by self-governing communities to submit draft resolutions. Importantly, this right was not established at the

${ }^{2}$ Article 2 of the European Charter of Local Self-Government emphasizes that "[t]he principle of local self-government shall be recognised in domestic legislation, and where practicable in the constitution." The European Charter of Local Self-Government is a document adopted by the European Council on October 15, 1985 and ratified in full by Poland on April 23, 1993 (Europejska Karta Samorzadu Lokalnego sporządzona w Strasburgu dnia 15 października 1985 r., Dz. U. 1994, No. 124, item 607). The Polish ratification document was handed to the Secretary General of the Council of Europe on November 22, 1993, while its provisions entered into the Polish legal order on March 1, 1994. 
constitutional or statutory levels. The procedure in question was only established in the statutes of self-government units, which initially aroused doubts from some administrative courts. As time went by, however, the attitude prevailed whereby citizens' initiative was allowed to be exercised within the existing legal order, an attitude significantly supported by the ruling of the Supreme Administrative Court of 2013 which stated that this form of direct democracy complied with law (Rachwał, 2016, p. 21).

Also in the scholarly literature the opinion prevails that citizens' initiative is part of the legal order. For instance, Agata Obrzut notes that the fact that a self-government entity determines who has the right to initiate resolutions is a manifestation of this entity's autonomy and independence within the decentralized political system (Obrzut, 2010, p. 28).

Thus, citizens' draft resolutions can be submitted on the basis of the statute of the self-government entity, and also take the form of motions as provided for in the Code of Administrative Procedure. Interestingly, there are also self-government entities which provided in their statutes for a special variation of the right to initiate resolutions granted to rural administrative units (Polish: sołectwo) and housing estates.

Further development of the citizens' right to initiate resolutions can be expected. This optimism is justified by the provisions in the Law of January 11, 2018, on the amendments to certain laws in order to increase civil participation in the processes of election, operation and supervision of certain public entities (Ustawa z 11 stycznia 2018 r. o zmianie niektórych ustaw w celu zwiększenia udziału obywateli w procesie wybierania, funkcjonowania $i$ kontrolowania niektórych organów publicznych, Dz. U. 2018, item 130). The broader presence of citizens' initiative, strengthened by the law, in decision-making procedures at the municipal, district and provincial levels should increase the extent of interested circles participating in the system of local and regional authorities exercising their powers.

Alongside the institutions of direct democracy which clearly facilitate stronger social participation, the significance of the development of metropolitan areas and the spatial expansion of cities should be noted, with their considerable resource, namely inhabitants who are involved in working for the common good. Benjamin R. Barber emphasizes that "it is in the cities that creativity sparks, communities consolidate and the idea of citizenship is implemented" (Barber, 2014, p. 18).

It should be borne in mind, however, that the advancing metropolization is interpreted as a significant economic factor of development, which is repeatedly stressed in the reports by national and foreign organizations and institutions (e.g. the studies by the OECD and the EU). That is why the rational management of metropolitan areas poses an extremely important challenge, due to their economic, academic and cultural importance (Edwarczyk, 2015, p. 303).

Current urban transformations are qualitative much more than quantitative. Metropolises are an outcome of globalization and combine two kinds of spaces - the global and the local ones. In order to assess the competitive position of modern metropolises, such parameters as population and GDP are important, as well as their network connections with other cities in Europe and worldwide.

Metropolization is one of crucial factors in the development of modern states. One needs to realize that modern metropolises are the main drivers of growth, having at their disposal all the necessary elements to build competitive economies, namely a skilled 
workforce, financial institutions, research and development hubs, as well as technical and social infrastructure (Kaczmarek, 2008, p. 15).

A question emerges in this context of the importance of self-government in the process of the development of agglomerations and the relation between this process and society. It is particularly important to indicate the modified role of self-government in the multi-level governance system. Accelerating this type of collaboration can be fundamental for the socio-economic development at the local and regional levels on the one hand, and can stimulate considerable changes in the implementation of urban policies on the other. The multi-level governance system can be especially efficient when implementing metropolitan governance.

Governance as a concept means the management of complex communities by way of coordinating the activities of entities from different sectors. It is therefore a network of interdependence, cooperation and partnership relations which is the outcome of the demonopolization of state authorities, and it thrives particularly in metropolitan areas. Governance is characterized by an innovative approach to political decision-making while constituting a new method of dispersed governance, different from the old, hierarchical model where state authorities exercise sovereign control over the people and groups forming civic society (Ruszkowski, 2013, p. 16).

State authorities need to take certain measures to facilitate these processes in metropolitan areas. Interestingly, the issues related to the development of metropolitan areas have been addressed by key strategic documents in Poland, in particular the Long-term National Development Strategy 2030. Poland 2030. Third Wave of Modernity. It calls for the metropolitan network to be rapidly developed by means of drawing up new legislative and organizational solutions.

The European Union is pursuing the same goal. The regional policy in the 2014-2020 programming period departed from the sectoral governance model in favor of an integrated and local approach. This is reflected in recognizing the importance of urban areas in the development of Europe and in strengthening the urban dimension of current cohesion policy (Zielona Księga, p. 6).

For a long time, Polish and EU strategic documents which addressed metropolitan issues did not translate into statutory regulations stipulating the founding principles for such associations of self-government units. Supporting metropolitan processes and urban self-governments can hardly be identified as a priority for the political class in Poland, regardless of the government's party affiliation. The debate launched during the Civic Platform - Polish People's Party coalition was not treated with due attention, which was why it failed to produce material outcomes for a long time. ${ }^{3}$

${ }^{3}$ The draft law on the metropolitan district, adopted by the Parliamentary Club of Civic Platform on July 30, 2013, attempted to determine the operating principles of legally distinct metropolitan areas. This draft met with criticism, however, during parliamentary discussions and social consultations. Particular concerns were raised by the fact that metropolitan districts would be included in the current territorial division of the country. The initiators of the draft stressed the fact that this new organizational unit would not curb the competence of other local self-government structures, but the text of the draft regulation did not clearly indicate what future awaited the districts currently existing in the area of the envisaged metropolitan association. The draft anticipated that the supra-local tasks of key importance for the development of the whole of the agglomeration would be transferred to the metropolitan level, which was actually perceived as a restriction on the powers of cities with district status as well as of regions. Controversy was also raised by the solution 
The rule of the above coalition produced a somewhat belated result in the form of the Law of October 9, 2015 on metropolitan associations (Ustawa z dnia 9 października 2015 r. o zwiazkach metropolitalnych, Dz. U. 2015, item 1890 and Dz. U. 2016, item 2260). The implementation of the regulations stipulated in this law stalled because of the electoral calendar and the political change brought about by the 2015 parliamentary elections. Initially, the majority government of Law and Justice and its coalition partners did not continue the process of metropolitan reform launched by their predecessors despite the fact that President Andrzej Duda signed the law. The political conflict between Civic Platform and Law and Justice, unprecedented in Poland's recent history, did not invite a rational exchange of ideas on the future of metropolitan associations. The new government addressed this issue after several months and opted for a slightly different solution. They gave up the idea of forming these types of associations throughout the entire country and focused on providing relevant regulations pertaining solely to the area of the Silesian Region, where efforts had been made to consolidate metropolitan ties for a decade.

As early as 2007, the mayors of the fourteen largest cities in Upper Silesia and Zagłębie established the Upper Silesian Metropolitan Association as a form of voluntary cooperation between cities with the rights of districts in the Katowice conurbation. The Association became a natural partner for the government at the time of drafting the new law, the draft of which the Minister of the Interior and Administration submitted for consultation to the authorities of the Association on April 29, 2016. The stage of social consultations was concluded on September 26, 2016, when the government adopted the draft law on metropolitan association in the Silesian Region. It was passed on March 9, 2017 under the same title (Ustawa z dnia 9 marca 2017 r. o związku metropolitalnym w województwie ślaskim, Dz. U. 2017, item 730).

This law defines a metropolitan association as an organization of municipalities in the Silesian Region, characterized by strong functional links and advanced urbanization processes, which are located in a spatially coherent area and inhabited by a minimum of two million dwellers (Article 1). The metropolitan association performs public tasks on its own behalf and at its own responsibility; it is a legal person and its independence is judicially protected (Article 2).

Unfortunately, other urban areas did not obtain similar legislative solutions, which is why local initiatives continue to be implemented there. ${ }^{4}$ However, it is clear that such ventures, albeit commendable, will not lead to a fundamental qualitative change in terms of the local development and organization in metropolitan areas. This goal requires relevant legislative and financial instruments, as well as the increased participation of social partners in the system of public governance.

There are, however, also other areas of operation of self-government which - when consolidated - can contribute to better quality of the political system in Poland. They

whereby, on the day of its establishment, the metropolitan district would by law take over fixed assets and other assets in the possession of the local self-government units included in this metropolitan district.

${ }^{4}$ A good example of this involvement of the local self-government is provided by the establishment of the Poznan Metropolis Association, which was registered on April 29, 2011. The main goal of the Association is to coordinate inter-municipal cooperation and to implement the common Development Strategy - Poznań Metropolis 2020. The Association includes the City of Poznań, the Poznań district and 21 municipalities within the agglomeration. This clearly is a significant step towards building metropolitan awareness, both among local authorities and residents. 
include the gradual expansion of the role of self-governments in the implementation of regional policies. In this context, the concept of local capital deserves to be mentioned, which should be seen as the basis for the endogenous development of every territory. The relational structure of local capital includes human capital, social capital, material capital, financial capital as well as technological and organizational innovation. If a set of such factors simultaneously exist and interpenetrate, the conditions for initiating and conducting the development processes of individual territories emerge.

Paweł Churski stresses the fact that development which takes advantage of the elements making up the local capital of individual territories can be achieved only provided that self-governments enjoy complete independence and flexible control instruments are implemented at the EU and national levels (Churski, 2018, p. 44).

Another extremely important factor involves the consolidation of the institutions of special self-government, which - as associations under public law - should constitute a significant element of the democratic regime structure. It is therefore worth paying attention to the position of special self-government in the legislative order in Poland, including also constitutional regulations.

\section{Special self-government in the political system of Poland}

The term special self-government refers to mandatory associations under public law which exercise authority primarily over the professional and business operations of specific categories of persons, and which perform their tasks of the decentralized portion of state administration on a par with self-government entities. The Constitution directly mentions professional self-government and provides also for other kinds of self-government to be established. Regrettably, the legislator failed to clarify what kind of selfgovernment is referred to. Taking into account the reservations stating that this type of self-government shall not limit the freedom to undertake business operations, it is more than likely that what is meant here is business self-government.

Including special self-government in the Constitution is certainly significant in the context of taking steps aimed at the empowerment of professional and business circles. What is of fundamental significance, however, is that these institutions are granted genuine public and administrative competencies, which raises them in the hierarchy of the political system.

The position of professional self-governments in the political regime does not raise any serious objections from the formal and legal point of view. Professional self-government is a term used to describe an organization associating persons in the same profession, for the purpose of, among other things, guarding professional ethics and ensuring social protection to people in a given profession as well as performing a range of tasks that are typical of such associations, such as conducting the registers of persons authorized to work in a given profession. It is this public scope of the operations of professional self-governments that defines their character and distinguishes them from typical associations.

Professional self-government in Poland has been strengthened by including it in the Constitution. Article 17 of the Constitution of the Republic of Poland of April 2, 1997 stipulates that " $[\mathrm{b}] \mathrm{y}$ means of a statute, self-governments may be created within a profession in 
which the public repose confidence, and such self-governments shall concern themselves with the proper practice of such professions in accordance with, and for the purpose of protecting, the public interest." Undoubtedly, this provision facilitated the development and adoption of sixteen regulations of statutory rank, enabling the appointment of professional self-governments in the following professions: lawyers, legal advisors, medical doctors, veterinarians, notaries, nurses and midwives, pharmacists, statutory auditors, tax advisors, bailiffs, architects and construction engineers, patent attorneys, psychologists (not yet created), probation officers, laboratory diagnosticians and physiotherapists.

The current political practice and the attitude of the national government to corporations that represent the professions of public trust arouse serious concerns since their role is consistently marginalized. These disturbing processes are further strengthened by the populist depreciation of professional circles associated in self-governing chambers. The increasing interference of government administration in their operations poses an obvious risk to the powers of these self-governing structures, to the further consolidation of participatory processes, and ultimately to the promotion of democracy and civic society in Poland.

An equally serious concern pertains to the matter of the political status of the institutions representing the interests of business circles in the political system. An optimal solution is the statutory establishment of business self-governments and vesting them with a range of public competencies. Such a self-government should be a democratically appointed, common and possibly apolitical representation of entrepreneurial circles, in order to become a partner to both central administration and self-government. Unfortunately, current legislative solutions are far from the above, which results in the representatives of individual groups of entrepreneurs being driven by their particular or even selfish interests. Another outcome of the existing system is that central administration officers are unwilling to share their political influence and allow only periodical consultations, or they only make concessions to their acquaintances in political circles or simply to coteries.

In this context, it should be remembered that the lack of transparency in this field of public life may cause pathology in the economy, various kinds of "black lobbying", clientelism or state capitalism.

A question arises here of the extent to which business circles and other interest groups are able and willing to deal with these dangerous phenomena?

This is an opportune moment to refer here to the studies on the public choice theory represented by Mancur Olson. In his fundamental work, The Logic of Collective Action, Olson makes the assumption that persons forming a group of interest are characterized by self-interest and making rational calculations of costs and benefits. He defines such a group in terms of a voluntary agreement of people who have rationally calculated that it is more profitable to achieve their respective private interests by means of group rather than individual effort (Olson, 1971; Klimczak, 2001, pp. 19-20). Developing his theory, Olson defied the traditional thesis put forward in sociology that groups are formed and operate due to the social nature of man and that they serve the purpose of soothing social conflicts on account of the symmetry of group interests. By this token, Olson questioned the concept of social incentives to associate which assumes that groups of interest are formed for the purpose of protecting their members from the adverse consequences of social changes and the actions of other groups, thereby balancing the system out. In all 
his works, Mancur Olson argues that groups hamper economic development, infringing on the balance of individual interest on the one hand and on the purely public actions of the state on the other.

Adopting Olson's concept, one has to take into account the possibility that groups of interest work for private benefits and reject the probability of their working for public benefit. This is because Olson envisages that the state and institutions it establishes suffice to ensure that the market operates in an orderly way, while the collective interest manifested as a claim made by a group within some area of public life can only be damaging. He emphatically stresses the fact that the state suffices if it is strong, while groups of interest act like petty thieves who are not interested in increasing the general prosperity but rather in their immediate benefits (Olson, 1998; Klimczak, 2001, p. 36). Such an uncompromising standpoint naturally meets with opposition from economists, and even more so from sociologists, who question the purely behavioral understanding of rationality and emphasize the social motives of group actions, such as reputation, a sense of belonging to a community, being a good citizen or the social responsibility of business. A compromise could be achieved by adopting a concept of mixed motivation where separate social and economic motivations are taken into account.

Bożena Klimczak notes that, within the concept of mixed motivation for group actions, one should distinguish between the idea of the existence of group interest and the collective good which secures this interest. This approach leads to the opposition between the model of economic man applied in economy and the model of sociological man. The difference between these two lies in different roles they are expected to perform in various situations and in different principles corresponding to these roles. While economic man is expected to be efficient on the basis of his private calculation of cost and benefit, sociological man is expected to work for the public good, which requires him to observe the fundamental constitutional principles on which the market order relies. In sociology, as in the old institutional economics, this approach assumes the internalization of these principles, as well as of detailed standards. Economics, which applies the homo oeconomicus model, assumes that constitutional principles, detailed standards and operating models are exogenous. The fact that they are complied with is explained in terms of a social contract entered into due to rational selfishness (Klimczak, 2005, pp. 60-64). Does this approach leave room for the realization of the public good, though?

Anna Ząbkowicz stresses the fact the stronger the state, the greater the temptation for business to transfer competition from the field of economy to the area of politics in order to take over the rent, that is the income produced by another entity but redistributed by the state. As a consequence of such unproductive actions of the coalition in favor of the division of income, the system of input and reward, which is a feature of healthy market economy, is distorted. The collective actions of business in this context are assessed as parasitic and undesirable. That is why imposing restrictions is recommended, that is, establishing institutional barriers curbing such unproductive collaboration of entrepreneurs and the state (Ząbkowicz, 2003, p. 7). It seems that these economic barriers can be established by a universal business self-government that is a democratic representation of the entrepreneurial community. Undoubtedly, the elimination of the above threats is of the utmost importance from the point of view of how political and economic relations are formed in the state and how social capital is constructed. 
The institutions of business self-government involve primarily chambers of commerce and industry, chambers of crafts and agricultural chambers. These organizations have a statutory range of tasks which they perform as sovereign entities independent of other public administration bodies. The range of their tasks is a measure of the extent of the decentralization of state administration in the economy as well as an expression of trust the state places in the citizens who are obligatorily associated in the chambers, and of the belief that they are more competent in the field of local and regional economy than central government officers.

All the above types of chambers take initiatives that are permanently included in their area of activity and facilitate the improvement of the situation of individual business entities, achieve the objectives of local and regional development, and also have an impact on the economic policy of the state. This activity is performed through the chambers taking care with regard to the market order, the development of entrepreneurship, education and training systems, and through providing support for innovation and management of public services.

Business self-governments transform the community of entrepreneurs from individual, dispersed entities to an organized community in terms of public law, i.e. a local selfgoverning community vested with administrative authorities. As an association under public law, business self-government has a considerably greater opportunity to facilitate efficient actions to fulfil mediation, adaptation and even the innovative functions of the political system.

Unfortunately, the business chambers operating in Poland do not have personality under public law. That is why they can be treated only as business associations instead of the entities of genuine business self-government. A particular deficiency of the current legislative order is the muddle of matters related to voluntary entrepreneurial associations formed with the main purpose of representing their particular interests with the issues of business self-governance. Making business associations, which are private unions, universal (mandatory) is utterly unjustified because their internal organization, legal status and position in the administrative structure has little in common with real business self-government. This is a highly negative tendency whereby the establishment of the institutions of faulty self-government that do not have any specific functions under public law is promoted.

\section{Final remarks}

In conclusion, the significant role of broadly understood self-governance in the political system in Poland should be emphasized. This is true for self-government which enjoys an exceptionally prominent position in the structure of local authorities, but also for the professional and business self-governments which are frequently marginalized or even overlooked in political activities. The synergy effect obtained by combining the institutional and social potentials of these self-governments seems to be able to improve the efficiency of the political system in Poland and consolidate the participatory character of the state.

Self-governments are studied by the representatives of numerous academic disciplines. Depending on their methodological approach, scholars stress various aspects of 
self-governments' functioning. Lawyers treat self-governments primarily as a form of decentralized state administration. Sociologists approach self-government in the context of the formation of social relationships and groups. For theoreticians of organizations, in turn, self-government is primarily an internally integral structure exerting an impact on its surroundings; and geographers will focus on matters related to local governance and the specific nature of the systems of settlements and administration. While all the above disciplines make a profound contribution to studies on self-governance, they appear to pursue a more specialized approach to the issue, narrowing it down as a consequence. The same holds true for law studies, in spite of their unquestionable merits for the development of the theory of self-governance, among other things. In this context, the multiparadigm and more comprehensive sciences of politics and administration enjoy better prospects, because broadly understood self-governance, which has a genuine influence on the shaping of social relationships, remains closely connected with the mechanics of political life. As stressed above, the "politicality" of self-governing authorities is manifested, for example, by the fact that self-governments are the subject of political aspirations and figure in the field of the competition between political parties, which does not always work to self-governments' advantage. In the national, European, and even global dimensions, elections to self-governments attract increasing attention from researchers and political commentators, since these bodies have a genuine influence on how the political system functions.

Andrzej Antoszewski is right when he indicates that self-government is a particular form of public authority which binds the local community and the institutions working for this community's benefit in a coherent unity that can be named the local political system. Antoszewski also stresses the fact that this system embraces the asymmetrical social relations which are typical of any form of authority, and the decisions made by the selfgoverning institutions resolve the conflict of interests, which is yet another prerogative of such authorities (Antoszewski, 2008, p. 43). Undoubtedly, the processes taking place at the local, and especially regional, levels are political in nature and that is why they should remain a significant field of studies in political science. This is further justified by the fact that the discussion on self-governance is one of the essential areas of dispute over the political system in Poland where one party stresses the need for deeper decentralization and the further emancipation of citizens' groups organized in corporations, while their adversaries advocate the vision of a stronger state as an omnipotent organization that comprehensively regulates the social order. In the latter case, it should be borne in mind that the excessive etatism in the public sphere and restricting the participatory aspirations of citizens can lay the foundations for the depreciation of democratic institutions in the future.

\section{Bibligraphy}

Adamczyk M., Pastuszka S. (1985), Konstytucje polskie w rozwoju dziejowym 1791-1982, Warszawa. Ajnenkiel A. (1982), Polskie Konstytucje, Warszawa.

Antoszewski A., Herbut R. (2001), Systemy polityczne współczesnego świata, Gdańsk.

Antoszewski A. (2008), Istota władzy samorządowej, in: Polityka lokalna. Właściwości, determinanty, podmioty, eds. E. Ganowicz, L. Rubisz, Torun. 
Barber B. R. (2014), Gdyby burmistrzowie rządzili światem. Dysfunkcyjne kraje, rozkwitające miasta, Warszawa.

Blok Z. (1996), Władza lokalna, in: Podmiotowość społeczności lokalnych. Praktyczne programy wspomagania rozwoju, ed. R. Cichocki, Poznań.

Bombicki M. R. (1998), Konstytucje Polski. Nowy podział administracyjny kraju, Poznań.

Churski P. (2018), Podejście zorientowane terytorialnie (place-based policy) - teoria i praktyka polityki regionalnej, "Rozwój Regionalny i Polityka Regionalna", 41, pp. 31-50.

Dekret z 28 sierpnia 1944 r. o trybie powoływania władz I i II instancji, Dz. U. 1944, No. 2, item 8.

Dekret z dnia 23 listopada 1944 r. o organizacji i zakresie działania samorzadu terytorialnego, Dz. U. 1944, No. 14, item 74.

Dolnicki B. (1999), Samorzad terytorialny. Zagadnienia ustrojowe, Zakamycze.

Edwarczyk B. (2015), Rozwój obszarów metropolitalnych w świetle transformacji samorządu terytorialnego w Polsce w latach 1990-2014, "Ruch Prawniczy, Ekonomiczny i Socjologiczny", vol. 3.

Europejska Karta Samorzadu Lokalnego sporzadzona w Strasburgu dnia 15 października 1985 r., Dz. U. 1994, No. 124, item 607.

Heywood A. (2006), Politologia, Warszawa.

Izdebski H. (1991), Samorzad terytorialny w II Rzeczypospolitej, część II: Samorząd w latach 19331939, "Samorząd Terytorialny", no. 6.

Jagusiak B. (2011), Systemy polityczne państw sasiedzkich Polski, Warszawa 201

Kaczmarek T. (2008), Aglomeracja poznańska jako region badania i działania, in: Powiat poznański. Jakość przestrzeni i jakość życia, eds. T. Kaczmarek, A. Mizgajski, Poznań.

Klimczak B. (2001), Teoretyczne podstawy badania grup interesu na rzecz ładu rynkowego, in: Samorzad gospodarczy i zawodowy $w$ procesie powstawania ładu rynkowego $w$ Polsce, ed. B. Klimczak, Wrocław.

Klimczak B. (2005), Działania zbiorowe na rzecz ładu rynkowego w okresie transformacji ustrojowej w Polsce, in: Spór o samorzad gospodarczy w Polsce, ed. S. Wykrętowicz, Poznań.

Konstytucja Rzeczypospolitej Polskiej z dnia 2 kwietnia 1997 r., Dz. U. 1997, No. 78, item 483.

Kroński A. (1932), Teoria samorządu terytorialnego, Warszawa.

Łuczak A. (1973), Samorzad terytorialny w programach i działalności stronnictw ludowych 1918 1939, Warszawa.

Obrzut A. (2010), Inicjatywa uchwałodawcza mieszkańców, "Wspólnota”, no. 13.

Och J. (2014), Teoria i praktyka funkcjonowania samorząności w Polsce, "Krakowskie Studia Małopolskie", no. 19.

Olson M. (1965), The Logic of Collective Action, Public Goods and Theory of Groups, Cambridge.

Olson M. (1998), Why Poor Economic Policies Must Promote Corruption: Lesson from the East for All Countries, in: Institutions and Economic Organization in the Advanced Economies, eds. M. Baldassarr, L. Paanetto, E. S. Phelps, Houndmills.

Osiński J. (1999), Problemy aksjologii samorzadności lokalnej w krajach nordyckich i w Polsce, in: Samorzą gminny w Polsce. Doświadczenia i perspektywy, eds. B. Nawrot, J. Pokładecki, Poznań.

Podolak M., Żmigrodzki M. (2009), System polityczny i jego klasyfikacje, in: Współczesne systemy polityczne, eds. M. Żmigrodzki, B. Dziemidok-Olszewska, Warszawa.

Rachwał M. (2016), Obywatelska inicjatywa uchwałodawcza w Polsce w świetle prawa - wybrane zagadnienia, "Przegląd Politologiczny", no. 1.

Rajca L. (2010), Modele samorządu terytorialnego, in: Samorząd terytorialny w Europie Zachodniej, ed. L. Rajca, Warszawa.

Ruszkowski J. (2013), Governance i jego typy w systemie wielopoziomowym. Zamiast wstepu, in: Multilevel Governance w Unii Europejskiej, eds. J. Ruszkowski, L. Wojnicz, Szczecin-Warszawa. 
Ustawa z dnia 23 marca 1933 r. o częściowej zmianie ustroju samorzqdu terytorialnego, Dz. U. 1933, No. 35, item 294.

Ustawa z dnia 11 września 1944 r. o organizacji i zakresie działania rad narodowych, Dz. U 1944, No. 5 , item 22.

Ustawa z dnia 20 marca 1950 r. o terenowych organach jednolitej władzy państwowej, Dz. U. 1950, No. 14, item 138.

Ustawa z dnia 9 października 2015 r. o związach metropolitalnych, Dz. U. 2015, item 1890 and 2016, item 2260 .

Ustawa z dnia 9 marca 2017 r. o związku metropolitalnym w województwie ślaskim, Dz. U. 2017, item 730 .

Ustawa z 11 stycznia 2018 r. o zmianie niektórych ustaw w celu zwiększenia udziału obywateli w procesie wybierania, funkcjonowania i kontrolowania niektórych organów publicznych, Dz. U. 2018, item 130.

Wojtaszczyk K. A. (2003), Państwo wspótczesne, in: Społeczeństwo i polityka. Podstawy nauk politycznych, eds. K. A. Wojtaszczyk, W. Jakubowski, Warszawa.

ZąbkiewiczA. (2003), Stosunki między państwem i biznesem a wzrost gospodarki, “Środkowoeuropejskie Studia Polityczne", no. 1.

Zielona księga obszarów metropolitalnych (2012), Ministerstwo Administracji i Cyfryzacji, Warszawa.

Zyborowicz S. (2008), Samorzad jako forma realizacji polityki na poziomie lokalnym, "Przegląd Politologiczny", no. 1.

\section{Samorząd w systemie politycznym Polski}

\section{Streszczenie}

Jednym z największych osiągnięć procesu transformacji ustrojowej w Polsce jest szeroka decentralizacja sfery władztwa publicznego rozumiana jako system, w którym istnieje większa liczba samodzielnych ośrodków dysponujących kompetencjami publicznoprawnymi przy jednym centralnym. Będący egzemplifikacją decentralizacji samorząd stał się zatem ważnym elementem demokratycznego systemu politycznego, współtworząc sieć powiązań odnoszących się do podziału władzy, majątku i zasobów w społeczeństwie. Nie ulega wątpliwości, że działając na rzecz zorganizowanych korporacyjnie grup obywateli samorząd przyczynia się do podniesienia efektywności funkcjonowania władzy publicznej w wymiarze terytorialnym i specjalnym. Wychodząc z tego założenia należy zauważyć, że samorząd nie jest pojęciem jednowymiarowym odnoszącym się wyłącznie do stosunków terytorialnych. Ważną rolę w systemie reprezentowania interesów określonych środowisk odgrywa także samorząd specjalny, który wyodrębnia się według innych kryteriów. W jego ramach wyróżniamy przede wszystkim samorząd zawodowy i gospodarczy. Warto również podkreślić, że samorząd należy obecnie rozpatrywać z nieco innej perspektywy, nie tylko ze względu na kontekst administracyjno-instytucjonalny, ale również z punktu widzenia realizacji interesów zorganizowanych grup społecznych, a więc w kategoriach governance, co może poprawić funkcjonowanie systemu władzy lokalnej, na przykład w kontekście kształtowania się obszarów metropolitalnych. Harmonijny rozwój wszystkich form samorządu, bez względu na charakter więzi łączących ich członków, a także wzmacnianie procesów partycypacyjnych jest zatem jednym z warunków petryfikacji demokratycznego systemu politycznego.

Słowa kluczowe: system polityczny, samorząd terytorialny, samorząd specjalny 